\title{
Sistem Informasi Manajemen Penyewaan Alat Berat pada PT Suriaman Sentosa
}

\author{
Heavy Equipment Rental Management Information System at PT Suriaman Sentosa \\ Julius Ferbi ${ }^{1}$, Willy Junaidi ${ }^{2}$, Fransiska Prihatini Sihotang ${ }^{3}$ \\ ${ }^{1,2,3}$ Program Studi Sistem Informasi, STMIK GI MDP \\ e-mail: ${ }^{1}$ juliusferbi0302@mhs.mdp.ac.id, ${ }^{2}$ junaidiwilly@mhs.mdp.ac.id, \\ ${ }^{3}$ fransiskaps@mdp.ac.id
}

\begin{abstract}
Abstrak
PT Suriaman Sentosa merupakan sebuah perusahaan yang bergerak pada penyewaan alat berat. Dalam menjalankan proses bisnisnya sering terjadi kesulitan untuk mengetahui status alat berat, kekeliruan pada informasi jam operasional penyewaan alat berat, dan tidak adanya informasi maintenance alat berat yang berpengaruh pada usia pakai dan kinerja alat berat. Maka dari itu, perlu dirancang dan dibangun suatu sistem informasi manajemen penyewaan yang dapat memberikan solusi bagi perusahaan dalam menyeimbangkan data penyewaan, data alat berat, jam operasional alat berat, serta menghasilkan laporan-laporan yang berkaitan dengan penyewaan alat berat. PIECES digunakan dalam menganalisis masalah, lalu dirancang usecase diagram untuk menggambarkan kebutuhan sistem. Entity Relationship Diagram (ERD) digunakan untuk memodelkan struktur data dan Data Flow Diagram (DFD) digunakan dalam memodelkan proses. Aplikasi dibangun berbasis website, yang dikembangkan menggunakan html, Php dan Mysql. Sistem informasi ini dapat membantu mengatasi permasalahan yang terjadi pada PT Suriaman Sentosa dalam menjalankan kegiatan penyewaan alat berat.
\end{abstract}

Kata kunci: Penyewaan, Alat berat, Sistem Informasi Manajemen, Php, MySQL.

\begin{abstract}
PT Suriaman Sentosa is a company engaged in heavy equipment rental. In carrying out the business process, it is often difficult to find out the status of the heavy equipment, errors in the information on heavy equipment rental operating hours, and the absence of heavy equipment maintenance information which affects the service life and performance of the heavy equipment. Therefore, it is necessary to design and build a rental management information system that can provide solutions for companies in balancing rental data, heavy equipment data, heavy equipment operating hours, and producing reports related to heavy equipment rental. PIECES is used in analyzing problems, then a usecase diagram is designed to describe the system requirements. Entity Relationship Diagrams (ERD) are used to model data structures and Data Flow Diagrams (DFD) are used in process modeling. The application is built based on a website, which was developed using HTML, PHP and Mysql. This information system can help solve problems that occur at PT Suriaman Sentosa in carrying out heavy equipment rental activities.
\end{abstract}

Keywords: Rental, Heavy Equipment, Management Information System, Php, MySQL

\section{PENDAHULUAN}

Sistem informasi manajemen merupakan suatu sistem yang dapat membantu manajemen dalam pengumpulan data, pengolahan data serta analisis evaluasi data dan menyajikannya ke dalam batas informasi yang bernilai dan akhirnya sampai pada pengambilan keputusan yang berguna untuk mendukung fungsi operasi manajemen [1]. Alat berat dapat dikategorikan dalam 
beberapa klasifikasi, yaitu fungsional dan klasifikasi operasional [2]. Penggunaan alat-alat berat mulai menggantikan tenaga kerja pada sejumlah proyek yang cukup besar dikarenakan keterbatasan waktu dan tenaga manusia [3].

Alat berat merupakan faktor penting di dalam proyek-proyek kontruksi dengan skala besar. Tujuan penggunaan alat berat tersebut untuk memudahkan manusia dalam mengerjakan pekerjaan sehingga hasil yang diharapkan dapat tercapai lebih mudah pada waktu yang relatif singkat [4]. Penyewaan adalah perjanjian yang melibatkan beberapa pihak, pihak yang satu mengikatkan dirinya untuk memberikan kepada pihak yang lainnya kenikmatan dari suatu barang, selama suatu waktu tertentu dan dengan pembayaran suatu harga yang oleh pihak tersebut terakhir itu disanggupi pembayarannya [5].

Sistem informasi yang digunakan untuk menyajikan informasi yang digunakan untuk mendukung operasi, manajemen, dan pengambilan keputusan dalam suatu organisasi [6]. Suatu pendekatan yang terorganisir dan terencana untuk memberikan eksekutif bantuan informasi yang tepat dan dapat memberikan kemudahan bagi proses manajemen [7].

PT Suriaman Sentosa merupakan salah satu perusahaan penyewaan alat berat yang beralamat di jalan Residen Abdul Rozak No.10 Palembang. Perusahaan ini khusus untuk penyewaan alat berat seperti excavator, truk, motor grader, compactor. Alat berat tersebut disimpan di poll, poll merupakan tempat penyimpanan alat berat. Proses peminjaman alat berat yang hingga kini berjalan pada perusahaan tersebut adalah pelanggan terlebih dahulu mendatangi perusahaan untuk menyewa alat berat yang dibutuhkan, lalu administrasi mengecek ketersediaan alat berat yang diinginkan pelanggan, kemudian administrasi akan menyediakan surat kontrak sewa alat berat yang disewakan. Pelanggan dapat menyewa alat berat secara bulanan maupun tahunan dengan waktu penyewaan paling sedikit 200 jam. Perusahaan ini juga memberikan sopir dan operator untuk mengoperasikan alat berat tersebut.

Pimpinan sulit untuk mengetahui status alat berat yang ada di poll, sehingga pimpinan sulit untuk mengambil keputusan alat mana yang harus didahulukan untuk disewa ke pelanggan. Terkadang pimpinan harus datang ke perusahaan atau menelpon ke bagian administrasi untuk menanyakan kondisi dan status alat berat yang berada di poll. Administrasi sering kali lupa mencatat lama pemakaian alat berat yang disewakan, sehingga pada saat menghitung jam operasional alat berat tidak terhitung dengan benar. Sering kali administrasi lupa menghitung jam operasional alat berat sehingga alat berat tersebut lupa diservis dan menyebabkan terjadi kerusakan alat pada saat digunakan. Servis yang dilakukan juga tidak dicatat sehingga sulit untuk membedakan antara alat berat yang diservis maupun belum diservis.

Solusi yang akan diusulkan untuk PT Suriaman Sentosa, berupa sistem informasi manajemen yang berguna untuk mempelancar proses ketersediaan alat berat dan mengetahui kondisi alat berat dan status alat berat yang tidak terkontrol sebelumnya. Aplikasi ini juga dapat mengupdate secara cepat dan bersifat online yang saling berhubungan jika terjadi kesalahan dalam data alat berat dan pimpinan juga bisa melihat laporan bulanan, kondisi alat berat, ketersediaan alat berat yang ada di perusahaan dan pemakaian alat berat sehingga dapat terkontrol dengan baik.

\section{METODE PENELITIAN}

Penelitian ini dilakukan pada PT Suriaman Sentosa yang merupakan perusahaan yang bergerak pada penyewaan alat berat. Penelitian ini terdiri dari 6 langkah seperti yang tergambar pada diagram alir penelitian yang dapat dilihat pada Gambar 1. 


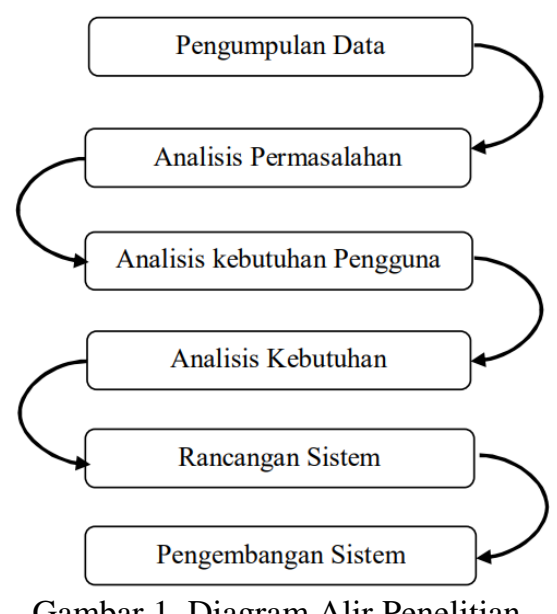

Gambar 1. Diagram Alir Penelitian

\subsection{Pengumpulan Data}

Pengumpulan data dilakukan dengan wawancara kepada pihak terkait pada PT Suriaman Sentosa, observasi mengenai hal yang berhubungan denganpenyewaan alat berat, dan melakukan studi literatur pada penelitian yang terkait dengan sistem informasi manajemen.

\subsection{Analisis Permasalahan}

Analisis permasalahan pada PT Suriaman Sentosa menggunakan kerangka PIECES yang terdiri dari Performance, Information. Economics, Control, Efficiency, dan Service, dapat dilihat pada Tabel 1.

Tabel 1. Analisis Permasalahan Kerangka PIECES

\begin{tabular}{|l|l|}
\hline \multicolumn{1}{|c|}{ PIECES } & \multicolumn{1}{c|}{ Permasalahan } \\
\hline Performance & Sulit mengetahui status alat berat. \\
\hline Information & $\begin{array}{l}\text { - Perusahaan sering mendapatkan kesalahan dalam pencatatan waktu } \\
\text { penyewaan. }\end{array}$ \\
\hline Econghitungan jam operasional tidak terhitung benar.
\end{tabular}

\subsection{Analisis Kebutuhan Pengguna}

Hasil analisis kebutuhan pengguna dapat dilihat pada Tabel 2. 
Tabel 2. Analisis Kebutuhan Pengguna

\begin{tabular}{|c|l|}
\hline User & \multicolumn{1}{|c|}{ Fungsi } \\
\hline Pimpinan & Pimpinan mempunyai hak untuk melihat detail laporan. \\
\hline Administrasi & $\begin{array}{l}\text { Administrasi mempunyai hak untuk melakukan menambah pelanggan, } \\
\text { melakukan penambahan detai alat berat, nencatat penyewaan alat berat. }\end{array}$ \\
\hline Lapangan & $\begin{array}{l}\text { Lapangan memiliki hak untuk mencatat jam operasional penyewaan alat } \\
\text { berat. }\end{array}$ \\
\hline DPA & DPA memeriksa kondisi alat berat dan melakukan permohanan servis. \\
\hline Maintenance & $\begin{array}{l}\text { Maintenance memliki hak untuk melakukan service alat berat yang diminta } \\
\text { oleh DPA. }\end{array}$ \\
\hline
\end{tabular}

\subsection{Analisis Kebutuhan}

Use Case Diagram adalah pemodelan awal yang menandakan sistem informasi akan dibangun. Dalam use case mencirikan sebuah interaksi yang terjadi pada satu atau lebih aktor terhadap sistem informasi yang akan dibangun. Use case dibuat dengan tujuan untuk mengetahui fungsi - fungsi apa saja yang terdapat dalam sistem informasi dan siapa saja yang berinteraksi dengan fungsi tersebut [8].

Pada diagram use case ini, digambarkan memiliki 5 (lima) aktor yaitu administrasi, divisi pengelolahan alat, petugas lapangan, maintenance, pimpinan. Diagram use case dapat dilihat pada Gambar 2. 


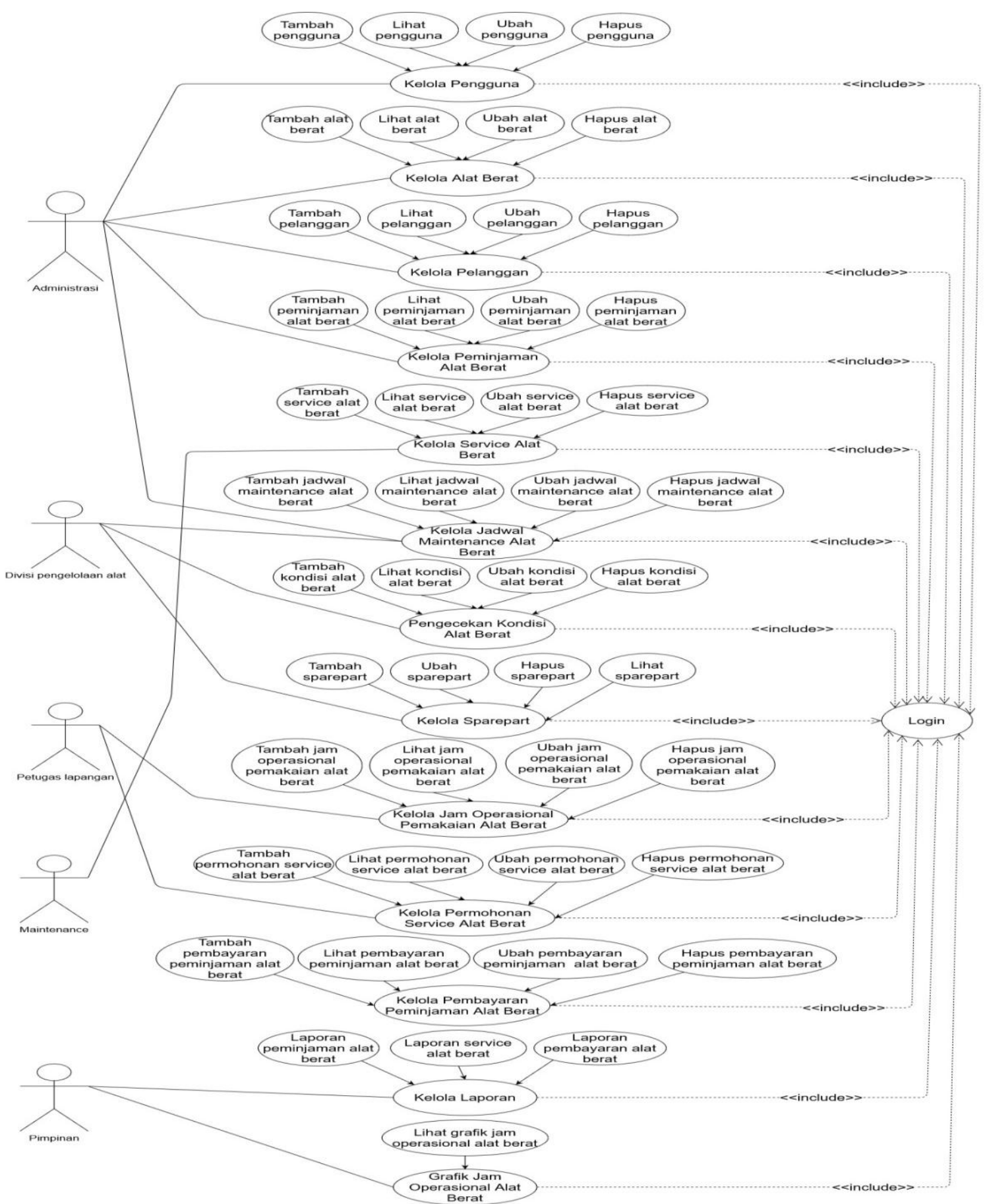

Gambar 2. Use Case Diagram

\subsection{Rancangan Sistem}

Rancangan sistem dibuat dengan menggunakan Unified Modeling Language. Unified Modeling Language (UML) adalah bahasa standar yang dapat digunakan untuk menjelaskan dan memvisualisasikan artifak dari proses analisis dan desain berorientasi objek [9]. Daigram diagram yang digunakan yaitu, Diagram Konteks, Diagram Dekomposisi, dan Data Flow Diagram (DFD) Level Nol Logis.

\subsubsection{Diagram Konteks}

Diagram Konteks dibuat untuk menentukan sebuah lingkup proyek awal. Diagram konteks menunjukkan antarmuka utama sistem yang dirancang. Dapat dilihat pada Gambar 3. 


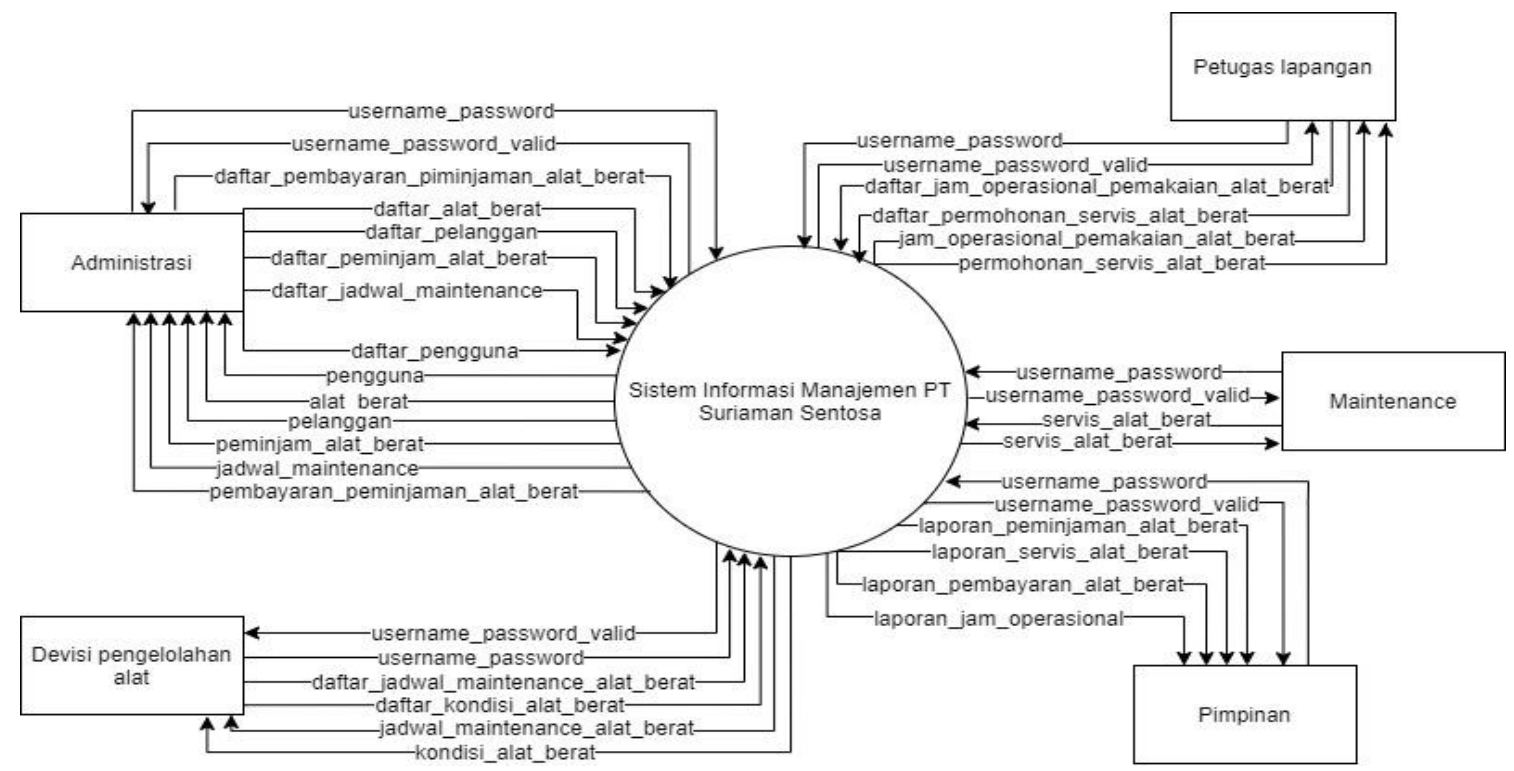

Gambar 3. Diagram Konteks

\subsubsection{Diagram Dekomposisi}

Diagram Dekomposisi menggambarkan beberapa suatu stuktur subsistem yang digunakan untuk membagi setiap aktifitas system menjadi tahap proses yang akan dijalankan. Dapat dilihat pada Gambar 4.

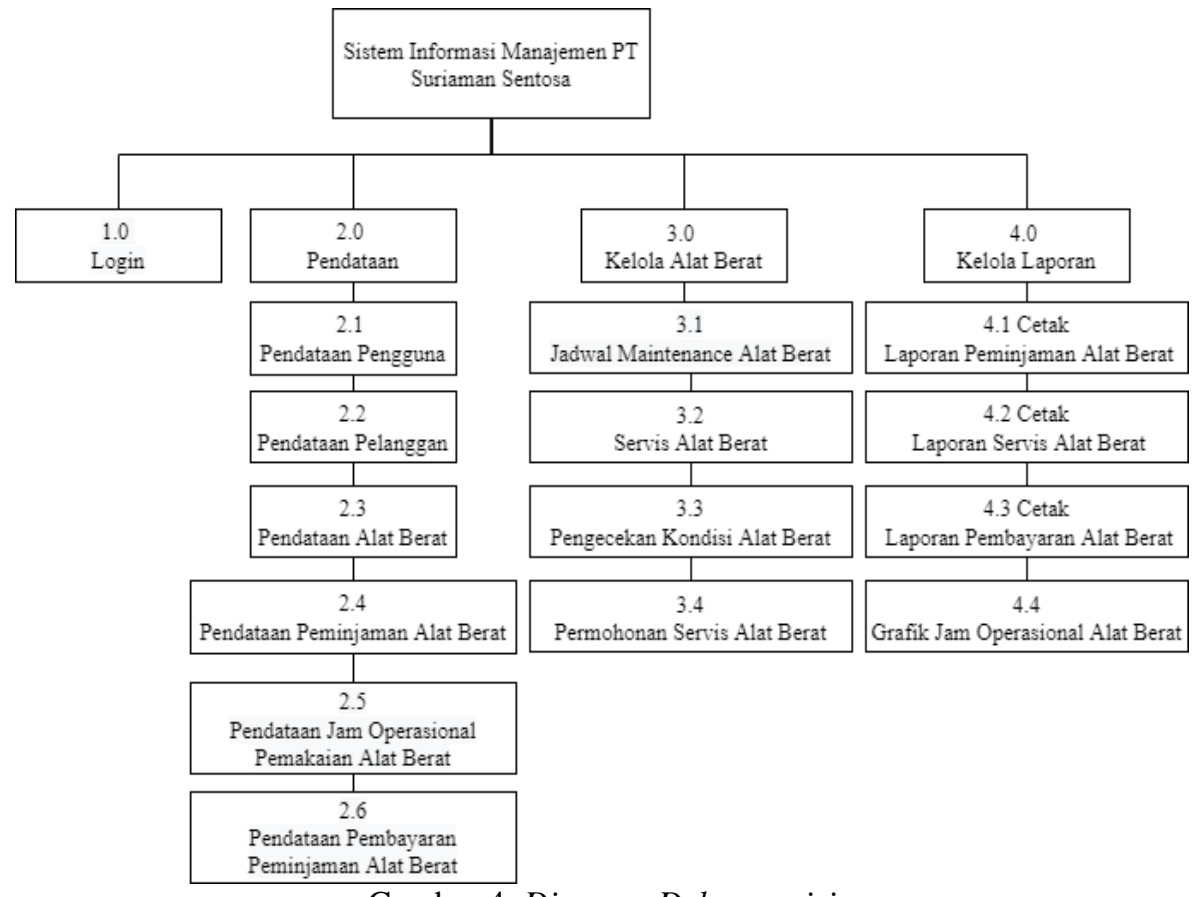

\section{Gambar 4. Diagram Dekomposisi}

\subsubsection{Data Flow Diagram (DFD)}

Data Flow Diagram (DFD) atau dalam bahasa indonesia menjadi Diagram Aliran Data (DAD) adalah representasi grafik yang menggambarkan aliran informasi dan transformasi informasi yang diaplikasikan sebagai data yang mengalir dari masukan (input) dan keluaran (output) [10]. Dapat dilihat pada Gambar 5. 


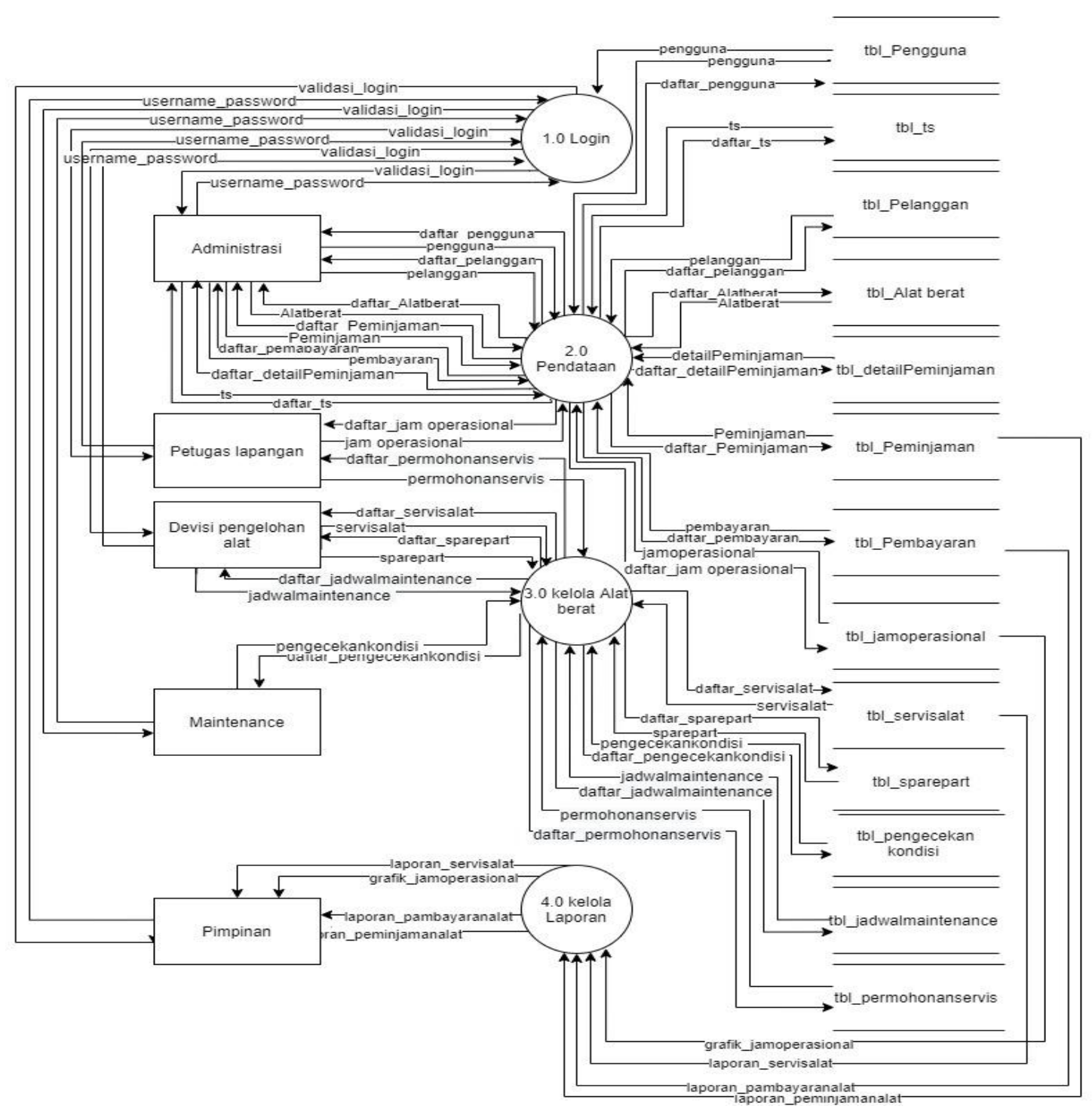

Gambar 5. Data Flow Diagram (DFD)

\subsection{Pengembangan Sistem}

Setelah merancang sistem dengan Diagram Konteks, Diagram Dekomposisi, dan Data Flow Diagram (DFD) Level Nol Logis, maka tahap selanjutnya adalah melakukan pengembangan sistem atau pengkodean. Sistem ini dibuat menggunakan bahasa pemrograman $P H P$ serta $M Y S Q L$ sebagai basis data.

\section{HASIL DAN PEMBAHASAN}

Pembahasan mengenai hasil dari penelitian sistem informasi manajemen PT Suriaman Sentosa sebagai berikut.

\subsection{Tampilan Antarmuka Login}

Tampilan halaman ini merupakan tampilan antarmuka halaman login untuk pengguna sistem pada perusahaan PT Suriaman Sentosa. Pengguna pada Sistem Informasi Produksi ini diantaranya yaitu administrasi, lapangan, maintenance, dpa dan pimpinan yang telah diberikan hak akses yang telah disesuaikan dengan aktivitas pekerjaannya. Dapat dilihat pada Gambar 6. 


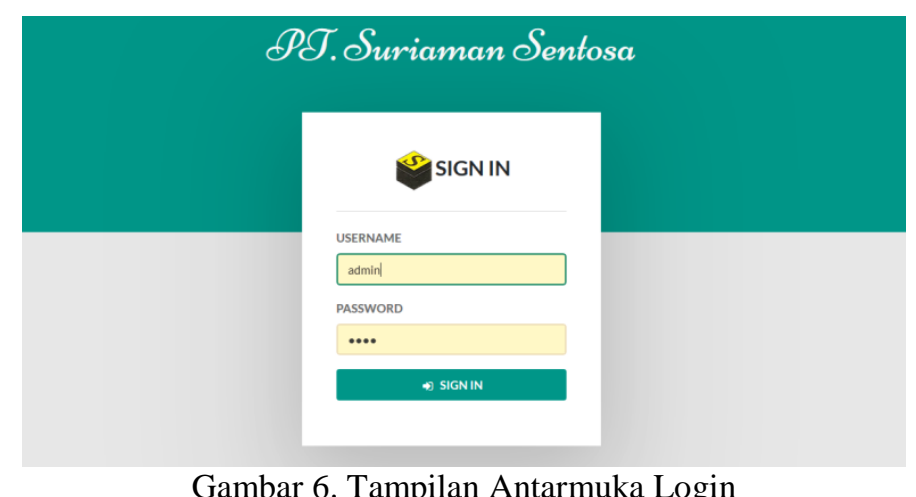

Gambar 6. Tampilan Antarmuka Login

\subsection{Tampilan Antarmuka Beranda}

Tampilan halaman ini merupakan tampilan antarmuka beranda pada admin. Dapat dilihat pada Gambar 7.

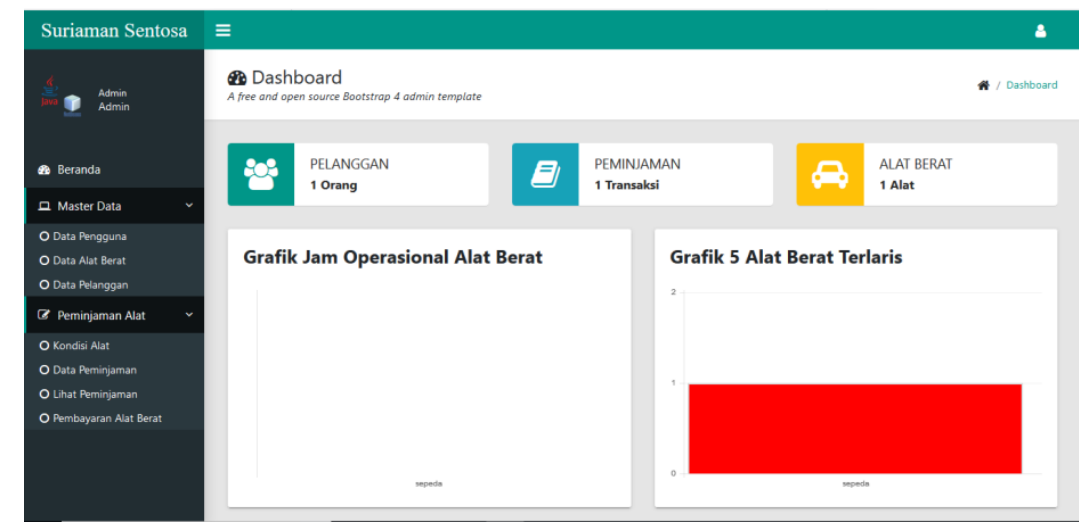

Gambar 7. Tampilan Halaman Antarmuka Beranda

\subsection{Tampilan Antarmuka Data Alat}

Tampilan halaman ini digunakan untuk melihat data alat berat yang tersedia dan disewakan yang dapat diakses oleh admin, dapat dilihat pada Gambar 8.

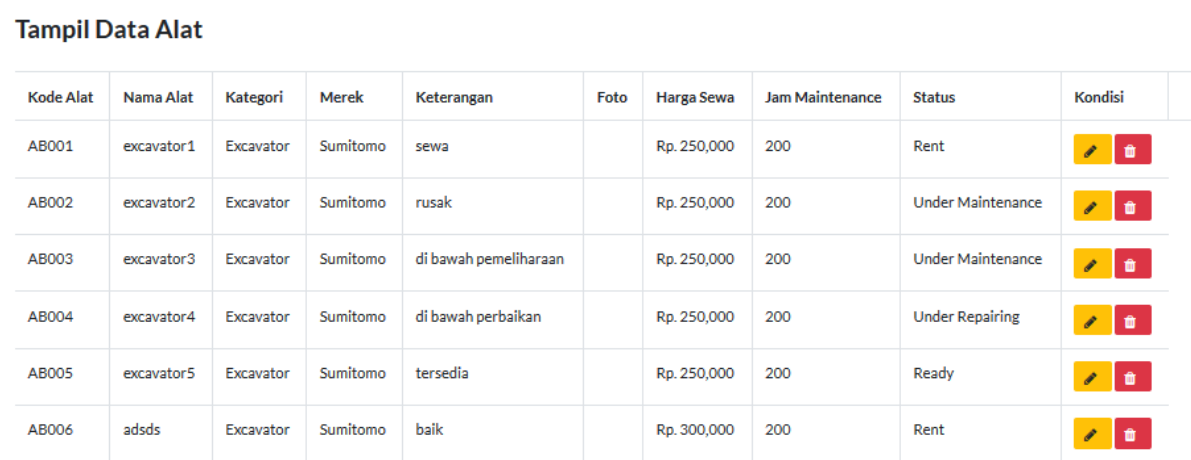

Gambar 8. Tampilan Antarmuka Tampil Data Alat

\subsection{Tampilan Antarmuka Grafik Jam Operasional Alat Berat}

Tampilan halaman ini merupakan tampilan antarmuka Grafik Jam Operasional Alat Berat untuk melihat jam operasional alat berat yang yang disewakan. Dapat dilihat pada Gambar 9. 


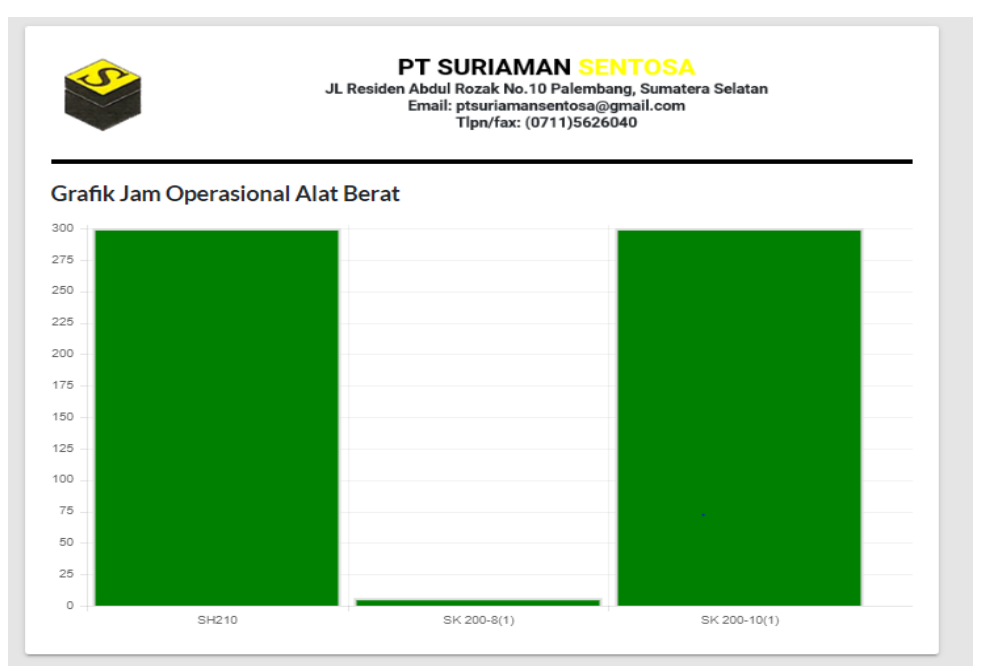

Gambar 9. Tampilan Antarmuka Grafik Jam Operasional Alat Berat

\subsection{Tampilan Antarmuka Jadwal Maintenance}

Pada halaman ini, data yang muncul diinput oleh bagian divisi pengelolaan. Bagian maintenance dapat melihat alat yang rusak, jika alat telah diperbaiki, maintenance dapat mengklik tombol selesai. Form jadwal maintenance dapat dilihat pada Gambar 10.

\section{Tampil Data Jadwal Maintenance}

\begin{tabular}{|c|c|c|c|c|c|c|c|}
\hline Show 10 & $\checkmark$ entries & & & & Search: & & \\
\hline No $t$ & Kode Alat $\uparrow \downarrow$ & Nama Alat $\quad \uparrow \downarrow$ & TgI Maintenance $\uparrow$ & Keterangan $\uparrow \downarrow$ & Status & $i \downarrow$ & $\uparrow \downarrow$ \\
\hline 1 & AB005 & excavator5 & $2020-05-12$ & gantioli & Under Maintenance & & $\checkmark$ Selesai \\
\hline 2 & ABO02 & excavator2 & $2020-05-13$ & rem blong & Under Maintenance & & $\checkmark$ Selesai \\
\hline Showing & 2 of 2 entries & & & & & Previo & Next \\
\hline
\end{tabular}

Gambar 10. Tampilan Antarmuka Jadwal Maintenance

\subsection{Tampilan Antarmuka Laporan Peminjaman Alat Berat}

Pada halaman ini, pimpinan dapat melihat laporan peminjaman alat dengan melakukan pencarian pertanggal atau perbulan. Form Laporan peminjaman alat dapat dilihat pada Gambar 11. 


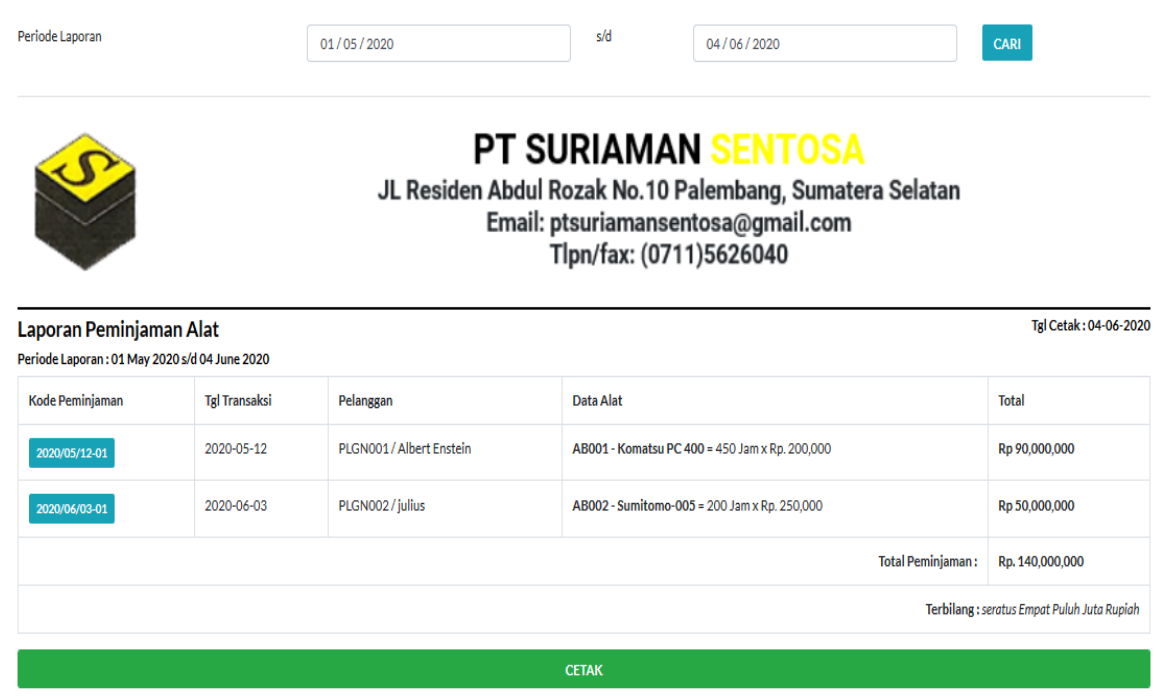

Gambar 11. Tampilan Antarmuka Laporan Peminjaman Alat Berat

\section{KESIMPULAN DAN SARAN}

Berdasarkan hasil pengembangan dan analisis yang telah penulis lakukan, maka dapat ditarik kesimpulan bahwa sengan aplikasi ini pimpinan mudah mengontrol status, kondisi, dan ketersediaan alat berat di perusahaan, sengan aplikasi ini dapat membantu perusahaan dalam merekap jam operasional dan maintenance pada alat berat, sengan aplikasi ini dapat mengetahui durasi penggunaan alat berat, laporan penyewaan, maintenance alat, status dan kondisi alat berat. Dalam perancangan dan pengembangan sistem ini, penulis sadar bahwa masih terdapat kekurangan pada sistem yang dibangun. Maka, penulis memberikan beberapa saran yaitu, Sebelum menggunakan website ini, terlebih dahulu diberikan pelatihan cara penggunaan kepada pengguna, sehingga website dapat digunakan dengan maksimal, Diharapkan kedepannya sistem informasi manajemen ini dapat ditambahkan fitur backup secara otomatis

\section{DAFTAR PUSTAKA}

[1] Rizan Machmud. 2013. Hubungan Sistem Informasi Manajemen dan Pelayanan Dengan Kinerja Pegawai pada Rutan Makasar. Jurnal Capacity STIE AMKOP Makassar, Vol.9 No.1 Maret 2013.

[2] Septiani Minda. 2019. Perencangan Sistem Informasi Penyewaan Alat Berat. JUSIM, Vol 04 No 02 Desember 2019.

[3] Iskandar fendy. 2017. Perancangan Aplikasi Penyewaan Alat Berat Berbasis Web pada PT. Indotruck Citra Pramata Jambi. PROCESSOR, Vol1. 12, No.2 Oktober 2017

[4] A. Kholil. 2012. Alat Berat, Rosada, Bandung.

[5] Subekti. 2014. Aneka Perjanjian. Citra Aditya Bakti, Bandung.

[6] Kadir, Abdul. 2014. Pengenalan Sistem Informasi. Andi Offset. Yogyakarta.

[7] Sutabri, T. 2016. Sistem Informasi Manajemen. Andi Offset, Yogyakarta. 
JTSI, Vol. 1, No. 2, September 2020: 142-152

[8] Rosa, AS., dan Shalahudin. 2013. Rekayasa Perangkat Lunak. Informatika. Bandung.

[9] Tunggal, AW. 2008. Supply Chain Management. Harvarindo. Jakarta.

[10] Rosa, AS., dan Shalahudin. 2014. Rekayasa Perangkat Lunak, Informatika, Bandung. 